\title{
Competência dos municípios para proteção e preser- vação do meio ambiente cultural
}

\author{
The districts' competence to protect and preserve the cultural \\ environment
}

\author{
Federico Nunes de Matos \\ Mestre em Direito Administrativo pela UFMG e Professor \\ Assistente / Universidade Federal de Ouro Preto. \\ federiconmatos@yahoo.com.br
}

Resumo O objetivo do presente artigo consiste em analisar, a partir de visão sistêmica de meio ambiente, a competência dos municípios para a proteção e a preservação do patrimônio cultural brasileiro. Embora a Constituição Federal de 1988 consagre a competência dos municípios para a tutela do meio ambiente cultural, diversos aspectos dessa competência são objeto de controvérsias doutrinárias e jurisprudenciais, como a possibilidade de os entes locais legislarem sobre tombamento e outros instrumentos de preservação. Parcela da doutrina e da jurisprudência sustenta a impossibilidade jurídica de os municípios realizarem o tombamento de bens estaduais e federais. Propõe-se, por meio da análise crítica da divisão constitucional de competências entre os entes federados, verificar a coerência do citado entendimento doutrinário e jurisprudencial. Palavras-chave MEIO AMBIENTE; PATRIMÔNIO CULTURAL; TOMBAMENTO; COMPETÊNCIA MUNICIPAL.

Abstract: The aim of this paper is to analyze, from a systemic view of the environment, the districts' competence to protect and preserve the Brazilian cultural heritage. Although the 1988 Federal Constitution recognizes the districts' competence to protect the cultural environment, several aspects of this competence are controversial in doctrine and jurisprudence, such as the ability of local entities to legislate on the listing of properties and other instruments of preservation. Part of the doctrine and case law supports the districts' legal impossibility to perform the listing of state and federal assets. Through a critical analysis of the constitutional division of competences between the federal entities, we propose that the consistency of such doctrinal and judicial understanding is checked.

Keywords ENVIRONMENT; CULTURAL HERITAGE; TIPPING; MUNICIPAL JURISDICTION. 


\section{INTRODUÇ̃̃o}

O constitucionalismo brasileiro, desde a Constituição de 1946, vem reconhecendo ampla autonomia político-administrativa dos municípios, chegando ao ponto de parcela da doutrina sustentar o status de ente federado aos mesmos. ${ }^{1}$ Seguindo tal tradição, a Constituição Federal de 1988 (CF) reconheceu um amplo feixe de competências aos municípios, cujo centro gravitacional encontra-se na noção de interesse local.

Neste estudo pretende-se analisar a competência dos municípios para a proteção e a preservação do meio ambiente cultural. Inicialmente, será demonstrada a inserção do patrimônio cultural como aspecto do meio ambiente globalmente considerado. Constatado que o patrimônio cultural constitui dimensão do meio ambiente, examinaremos o sistema constitucional de repartição de competências ambientais, visando compreender como a Constituição repartiu tais competências administrativas e legislativas entre os entes federados. Por fim, abordaremos a possibilidade jurídica de o município realizar o tombamento de bens públicos federais e estaduais, tendo em vista a proteção do meio ambiente cultural local.

\section{Patrimônio Cultural Como dimensão do meio ambiente}

A Constituição Federal de 1988, no "Título VIII - Da Ordem Social”, tratou da proteção ao patrimônio cultural no "Capítulo III - Da Educação, da Cultura e do Desporto" e da preservação ao meio ambiente no "Capítulo VI - Do Meio Ambiente". Embora o constituinte tenha estabelecido, por questões de sistematização legislativa, capítulos distintos para disciplinar o patrimônio cultural (art. 216) e o meio ambiente (art. 225), na prática os dois temas são indissociáveis. Vale ressaltar que o próprio constituinte concedeu tratamento homogêneo ao patrimônio cultural e ao meio ambiente, ao estabelecer, respectivamente, nos artigos $216, \S 1^{\circ}$ e 225 , caput da Constituição Federal, que incumbe ao Poder Público, com a colaboração da comunidade, o dever de preservá-los e defendê-los (cf. MIRANDA, 2006, p. 11).

No plano infraconstitucional, o meio ambiente foi definido de forma abrangente pelo art. $3^{\circ}$, I da Lei n. ${ }^{\circ}$ 6.938/1981 (Lei da Política Nacional de Meio Ambiente), como "o conjunto de condições, leis, influências e interações de ordem física, química e biológica, que permite, abriga e rege a vida em todas as suas formas". ${ }^{2}$ Celso Antonio Pacheco Fiorillo, ao analisar conjuntamente o conceito de meio ambiente

formulado pelo legislador ordinário com o comando do art. 225 do texto constitucional, conclui que "a definição de meio ambiente é ampla, devendo-se observar que

1 Neste sentido, cf. Meirelles (2006, P. 45-47), Braz (1994, P. 43-48) Ferrari (1993, p. 32-33). Em sentido contrário, cf. Silva (2005, p. 474-475), Castro (2006, p. 27-34).

2 Parcela substancial da doutrina entende que o conceito de meio ambiente consagrado no art. $3^{\circ}$, I da Lei n. ${ }^{\circ}$ 6.938/1981 foi recepcionado pela Constituição Federal de 1988 (FIORILLO, 2011, p. 72-73). 
o legislador optou por trazer um conceito jurídico indeterminado, a fim de criar um espaço positivo de incidência da norma" (2011, p. 73).

A doutrina contemporânea, baseada numa concepção holística, sistêmica ou unitária de meio ambiente, ${ }^{3}$ entende que o patrimônio cultural está compreendido na noção de meio ambiente. Seguindo tal concepção, Lúcia Reisewitz ${ }^{4}$ defende a inclusão do patrimônio cultural como objeto da tutela do direito ambiental:

O direito ambiental não está limitado àquilo que diz respeito à natureza, portanto o que chamamos de dado. Além da fauna, da flora, da qualidade do ar e da água, portanto de todo o equilíbrio ecológico, estão compreendidos em sua tutela os elementos criados pelo ser humano, ou seja, a ação humana modificadora da natureza, de maneira que toda a riqueza que compõe o patrimônio ambiental transcende a matéria natural e incorpora também um ambiente cultural, revelado pelo patrimônio cultural. (2004, p. 63).

Para Ana Maria Moreira Marchesan, o legislador constituinte, ao reconhecer o direito fundamental ao meio ambiente ecologicamente equilibrado, essencial à sadia qualidade de vida (art. 225 da CF), "não deixou de inserir em tal direito a dimensão cultural, porque não há falar em vida dotada de qualidade quando se arredam os valores associados à cultura" (MARCHESAN, 2007, p. 109). Para tal corrente doutrinária, estão compreendidas na noção de meio ambiente as dimensões ${ }^{5}$ relativas ao meio ambiente natural, ao meio ambiente artificial (urbano), ao meio ambiente cultural e ao meio ambiente do trabalho. ${ }^{6}{ }^{7}$

3 Para aprofundamento nesta concepção holística de meio ambiente, na doutrina e jurisprudência estrangeira e na pátria, cf. Marchesan (2007, p. 73-100).

4 No mesmo sentido, cf. Pires (2010, p. 140-141). Em sentido diverso, José Casalta Nabais (2010, p. 95-97) defende separação entre o patrimônio cultural e o patrimônio natural, uma vez que a Constituição portuguesa, assim como a brasileira, tratou das duas matérias em artigos distintos (artigos $66 .^{\circ}$ e $78 .^{\circ}$ da Constituição da República Portuguesa de 1976). No entanto, o citado autor português ressalva que a referida separação: “[...] como é fácil de calcular, não é nem pode ser absoluta ou de natureza estanque, já que não podemos esquecer que tanto o patrimônio cultural como o patrimônio natural integram os componentes ambientais humanos, nos termos do art. $17^{\circ}$ da Lei de Bases do Ambiente" (NABAIS, 2010, p. 96).

5 O vocábulo dimensões, conforme observa Ana Maria Moreira Marchesan (2007, p. 84, n. 351), é empregado “[...] para insinuar a união entre esses 'meio ambientes' e arredar a perspectiva da fragmentação. A identificação das diversas facetas (ou dimensões) do meio ambiente é usualmente feita para facilitar a perfeita identificação da atividade degradante e dos meios adequados para coibi-la".

6 Neste sentido, tem-se a famosa definição de meio ambiente formulada por José Afonso da Silva (1998, p. 12): "interação do conjunto de elementos naturais, artificiais e culturais que propiciam o desenvolvimento da vida em todas as suas formas".

7 Adverte Celso Antônio Pacheco Fiorillo (2011, p. 73) que: “A divisão do meio ambiente em aspectos que o compõem busca facilitar a identificação da atividade degradante e do bem imediatamente agredido. Não se pode perder de vista que o direito ambiental tem como objetivo maior tutelar a vida saudável, de modo que a classificação apenas identifica o aspecto do meio ambiente em que valores maiores foram aviltados. E com isso encontramos pelo menos quatro significativos aspectos: meio ambiente natural, artificial, cultural e do trabalho". 
Diante da constatação de que o patrimônio cultural constitui dimensão do meio ambiente, a doutrina conclui que os princípios do direito ambiental são aplicáveis à tutela dos bens culturais. ${ }^{8}$ No entanto, a aplicação de tais princípios à proteção do patrimônio cultural demanda

pequenas adequações aos mandamentos nucleares do Direito Ambiental, que na maioria das vezes foram cunhados com vistas dirigidas preponderantemente para o aspecto natural do meio ambiente. (MIRANDA, 2006, p. 23).

Com base nessa visão sistêmica, examinaremos a competência dos entes federados para a proteção e preservação da dimensão cultural do meio ambiente. Posteriormente, verificaremos a possibilidade jurídica de os municípios realizarem o tombamento de bens públicos estaduais e federais.

\section{COMPETÊNCIA DOS ENTES FEDERAdOS NA TUTELA DO MEIO} AMBIENTE CULTURAL

A análise das competências legislativas e administrativas acerca da proteção ao meio ambiente cultural deve ter, como ponto de partida, o art. $216, \S 1^{\circ}$ da Constituição Federal, que estabelece como imperativo que "o Poder Público, com a colaboração da comunidade, promoverá e protegerá o patrimônio cultural brasileiro". Podemos concluir que cabe aos entes políticos integrantes da federação brasileira, por meio de suas funções legislativas e administrativas, efetivar o citado comando constitucional, conforme divisão de competências traçada pelo legislador constituinte.

Por questão metodológica, analisaremos as competências legislativas e administrativas dos entes federados no que concerne à proteção à dimensão cultural do meio ambiente, em tópicos separados.

\section{COMPETÊNCIA ADMINISTRATIVA DOS ENTES FEDERAdOS NA TUTELA DO MEIO} AMBIENTE CULTURAL

Ao traçar a competência dos entes federados para a proteção e preservação do patrimônio cultural, o legislador constituinte estabeleceu que se trata de competência comum da União, dos Estados, do Distrito Federal e dos Municípios. Neste sentido, dispõe os incisos III, IV e $\mathrm{V}$ do artigo 23 da CF:

8 Para aprofundamento no estudo da aplicação dos princípios gerais do direito ambiental à tutela do patrimônio cultural (cf. MARCHESAN, 2007, p. 112-167). 
Art. 23. É competência da União, dos Estados, do Distrito Federal e dos Municípios:

$[\ldots]$

III - proteger os documentos, as obras e outros bens de valor histórico, artístico e cultural, os monumentos, as paisagens naturais notáveis e os sítios arqueológicos;

IV - impedir a evasão, a destruição e a descaracterização de obras de arte e de outros bens de valor histórico, artístico ou cultural;

$\mathrm{V}$ - proporcionar os meios de acesso à cultura, à educação e à ciência.

Vale salientar que não foi por mera coincidência que o legislador constituinte, nos incisos subsequentes, atribuiu tratamento homogêneo à competência dos entes federados no que tange à proteção e preservação ao meio ambiente natural. Dispõem os incisos VI e VII do artigo 23 da Constituição Federal:

Art. 23. É competência da União, dos Estados, do Distrito Federal e dos Municípios:

$[\ldots]$

VI - proteger o meio ambiente e combater a poluição em qualquer de suas formas;

VII - preservar as florestas, a fauna e a flora.

Percebe-se, mais uma vez, no texto constitucional, a tendência a conferir tratamento uniforme ao meio ambiente natural e ao meio ambiente cultural, demonstrando que as duas dimensões encontram-se estreitamente ligadas.

Se não bastasse a Constituição Federal estabelecer a competência comum da União, dos estados, do Distrito Federal e dos municípios para a proteção do meio ambiente cultural, o legislador constituinte deixou claro, no inciso IX do art. 30, a competência municipal para "promover a proteção do patrimônio histórico-cultural local, observada a legislação e a ação fiscalizadora federal e estadual". O referido dispositivo, além de reconhecer explicitamente a competência do município sobre a matéria, estabeleceu como norte teleológico delimitador de tal competência o "interesse local". ${ }^{9}$ Em outras palavras, a atuação do município na proteção e preservação do meio ambiente cultural deve necessariamente estar vinculada ao aspecto local.

\footnotetext{
9 A expressão "assuntos de interesse local" foi empregada pelo art. 30, I da Constituição Federal para delimitar a competência legislativa do município. No entanto, a vinculação ao interesse local será utilizada como critério para delimitação de todas as áreas de atuação do município. Neste sentido, têm-se as lições de Hely Lopes Meirelles (2006, p. 136): "O que importa fixar, desde já, é que os assuntos de interesse local surgem em todos os campos em que o Município atue com competência explícita ou implícita".
} 


\section{Competência legislativa dos entes Federados NA TUTEla do Meio} AMBIENTE CULTURAL

Ao definir a competência legislativa dos entes federados, a Constituição Federal de 1988, no art. 24, VII, estabeleceu que compete concorrentemente à União, aos estados e ao Distrito Federal legislar sobre "proteção ao patrimônio histórico, cultural, artístico, turístico e paisagístico".

Mais uma vez, a Constituição Federal optou por conferir tratamento uniforme entre o meio ambiente natural, cultural e artificial (urbano), já que os incisos I e VI do art. 24 do texto constitucional, respectivamente, fixaram competência concorrente da União, dos estados e do Distrito Federal para legislar sobre o "direito urbanístico", assim como sobre "floresta, caça, pesca, fauna, conservação da natureza, defesa do solo e dos recursos naturais, proteção ao meio ambiente e controle da poluição".

Com a divisão de competência legislativa traçada em matéria de meio ambiente artificial, natural e cultural, disposta, respectivamente, pelos incisos I, VI e VII do art. 24 do texto constitucional, conclui-se que cabe ao legislador federal estabelecer normas gerais em matéria de proteção ao meio ambiente (art. $24, \S 1^{\circ} \mathrm{CF}$ ) e ao legislador estadual e distrital suplementá-las (art. 24, § $2^{\circ}$ da CF). Na ausência de normas gerais editadas pela União, cabe aos estados exercer competência legislativa plena, de forma a atender às suas peculiaridades regionais (art. $24, \S 3^{\circ}$ da CF). No entanto, a edição posterior de normas gerais pela União suspende a eficácia da norma estadual ou distrital, no que esta lhe for contrária (art. 24, $\S 4^{\circ}$ da $\mathrm{CF}$ ).

Partindo da análise literal e isolada do art. 24, inciso VII da Constituição Federal, poder-se-ia concluir que o município carece de competência para legislar sobre o meio ambiente cultural, já que o citado dispositivo constitucional não menciona os entes políticos locais. No entanto, parcela da doutrina, ${ }^{10}$ baseada em análise sistêmica do texto constitucional, reconhece competência legislativa municipal para a suplementação da legislação federal e estadual, no que couber, em matéria de meio ambiente cultural, com fundamento no art. 30, I e II, da Constituição Federal. ${ }^{11}$ Car-

10 Neste sentido, ver Rabello (2009, p. 32-33), Miranda (2006, p. 89-94), Marchesan (2007a, p. 228230), Silva (2001, p. 43-44), Meirelles (2006, p. 565), Santana (1998, p. 151-157), Custódio (1995, p. 37-38), Leite (1993, p. 654), Silva (2010, p. 116), Bandeira de Mello (2011, p. 917), Faria (2010, p. 66), Paiva (2010, p. 40), Silveira (2011, p. 297).

11 Neste sentido, Maria Coeli Simões Pires (1999, p. 154), em artigo no qual analisa a autonomia municipal, explica de forma magistral o referido entendimento: "No art. 24, tratou o constituinte de disciplinar a competência no âmbito da legislação concorrente. Não incluiu nesse condomínio o Município. Contudo, a referida ausência não significa, segundo sustentam alguns autores, que o Município não tenha competência nesse campo concorrencial, pois restar-lhe-ia a competência para legislar sobre matéria de interesse local, com fulcro no art. 30, I, bem assim para suplementar a legislação federal e a estadual, no que couber, a teor do art. 30, II, podendo incidir sobre matéria constantes do art. 24". 


\section{los Frederico Máres de Souza Filho, ${ }^{12}$ baseado na noção de interesse local, expõe tal entendimento:}

Compreende peculiar interesse do município e evidente interesse local o cuidar das coisas da cidade e é nela que estão concentrados os bens culturais, sejam federais, estaduais ou locais. Os bens móveis, as obras de arte, peças históricas, documentos e livros, estão em regra acondicionados em museus espalhados pela cidade. Os imóveis, com predominância dos conjuntos e prédios urbanos, mas também muitas vezes as paisagens notáveis e mesmo os sítios arqueológicos, paleontológicos ou ecológicos, estão inseridos dentro das cidades, causando serviços e obrigações às autoridades municipais além da obrigação constitucional de protegê-los. A existência destes bens geram problemas de ordem urbanística, de trânsito, de ambientação, de visualização, de poluição que devem ser resolvidos por normas municipais, exigindo que as autoridades locais contem com serviços especiais que, fruto de sua autonomia, devem auto-organizar.

Assim, é claro que o Município tem competência para legislar sobre o patrimônio cultural referente ao seu território, a bens que tenham relevância para a cultura da municipalidade. É evidente que estes bens podem ser também referentes ao Estado ou à Nação, ou mesmo à humanidade, mas continuam sendo de interesse local, e podem não ser da Nação, e então, com maior razão, compete ao Município legislar a sua proteção. (2008, p. 120).

Tal entendimento também tem sido albergado pela jurisprudência. ${ }^{13}$ Neste sentido, posicionou-se o Supremo Tribunal Federal:

A Constituição, ao garantir aos Poderes Públicos o encargo da proteção desses bens, atribuiu-o igualmente ao município, dotando-o da mesma potencialidade e virtualidade que a cada um toca, da competência para, na órbita de sua ação, coibir excessos que, se consumados, poriam em risco toda a estrutura das utilidades culturais e ambientais.

A gênese dessa competência decorre do inciso II, do art. 15, da EC 01/69 (atual artigo 30, I e IX, da Carta Política de 88), assecuratório da autonomia municipal, no que tange aos interesses do município.

12 No mesmo sentido, ver Meirelles (2006, p. 656).

13 Cf. MINAS GERAIS. Tribunal de Justiça, Apelação Civil no 000.221.584-6/00. Relator: Desembargador Francisco Figueiredo, j. 05/06/2002. MINAS GERAIS. Tribunal de Justiça, Apelação Civil n ${ }^{\circ}$ 000.256.230-4/00. Relator: Desembargador Bady Curi, j. 07/11/2002. 
O patrimônio cultural é elevado pela ordem constitucional ao patamar dos valores fundamentais a serem protegidos, resguardados e preservados, e que impõem sejam promovidos pelos órgãos do Estado. Nos três estágios dos Poderes Públicos, tanto o municipal, o estadual, como o federal, atribuem-se-lhes as competências para a expedição de normas reguladoras para a garantia da intangibilidade desses bens públicos, o que não impede, por exemplo, que no Rio de Janeiro se reconheça como patrimônio histórico o Largo do Boticário.

As três instâncias administrativas se realizam harmonicamente nos limites de atuação de cada um deles. Assim sendo, tem o Município delegação constitucional para legislar sobre assunto que revele ser de interesse local a exigir medidas restritivas, consabido que o interesse social se sobrepõe ao individual. (BRASIL. Supremo Tribunal Federal, Recurso Extraordinário no 121.140-7-RJ. Relator: Ministro Maurício Corrêa. D.J. 23/08/2002).

\begin{abstract}
Apesar de parcela da doutrina ${ }^{14}$ e da jurisprudência ${ }^{15}$ prosseguir defendendo a incompetência legislativa do município para legislar sobre o meio ambiente cultural, prevalece o entendimento de que o município, baseado no art. 30, incs. I e II da Constituição Federal, possui competência para legislar sobre a proteção ao patrimônio cultural local, suplementando, no que couber, a legislação federal e estadual. ${ }^{16},{ }^{17}$
\end{abstract}

14 Argumenta Eduardo Tomasevicius Filho (2004, p. 235), criticando a posição daqueles que entendem ter o município competência para legislar sobre proteção ao patrimônio cultural: "No nosso entender, essa argumentação não procede, porque o art. 24, VII, da Constituição Federal reserva expressamente à União e aos Estados essa competência legislativa. Isso porque, sob a alegação de 'interesse local', permitir-se-ia aos municípios legislarem sobre qualquer assunto, o que não parece ser razoável. Logo, a contrario sensu, foi vedado aos municípios legislarem sobre essa matéria”. No entanto, o próprio autor reconhece que a questão não é pacífica na jurisprudência, citando algumas decisões judiciais em sentido diverso (TOMASEVICIUS FILHO, 2004, p. 245). (Cf. COPOLA, 2004, p. 642).

15 O Tribunal de Justiça de Minas Gerais, na Ação Direta de Inconstitucionalidade n. ${ }^{\circ} 40.647$, relativa ao art. 224 da Lei Orgânica do Município de Belo Horizonte, entendeu que os municípios não são detentores de competência para legislar sobre tombamento (cf. FARIA, 2010, p. 64). No mesmo sentido, entendeu o Tribunal de Justiça do Estado de Minas Gerais: "Os municípios não têm competência concorrente para legislar sobre a proteção de seu patrimônio histórico-cultural, mas devem utilizar os instrumentos de proteção previstos na legislação federal e estadual" (MINAS GERAIS. Tribunal de Justiça, Apelação Cível no 000.199.546-3/00. Relator: Desembargador Aloysio Nogueira, j. 31/06/2001).

16 Vale destacar que o mesmo entendimento prevalece no que tange à competência legislativa do município para a tutela do meio ambiente natural. Neste sentido, cf. FIORILLO (2011, P. 208-210), BRATZ (2011, P. 251-274), TRENNEPOHL (2008, p. 66-68).

17 Jair Eduardo Santana (1998, p. 153) posiciona-se no sentido de que a competência do município de legislar sobre o patrimônio cultural é subsidiária, nos seguintes termos: "por não ser essa competência legislativa da espécie primária, seguramente haverá o Município de atuar com obediência à legislação da União e dos Estados, para não haver invasão em seara onde não se lhe permite transitar”. Em sentido diverso, Jussara Aparecida Bratz (2011, p. 270), em trabalho voltado para análise 


\section{Tombamento COMO instrumento CONSTitucional de PROTEÇão aO MEIO AMBIENTE CULTURAL}

O art. 216, § 1º da Constituição Federal de 1988, ao instituir o dever do Poder Público, com a colaboração da comunidade, de promover e preservar o meio ambiente cultural, enumerou alguns dos instrumentos jurídicos vocacionados à tutela do patrimônio cultural brasileiro: a) inventário; b) registro; c) vigilância; d) tombamento; e) desapropriação; e f) outras formas de acautelamento e preservação.

Conforme observa Marcos Paulo de Souza Miranda (2006, p. 101), "o legislador constituinte ao fazer ressalva a outras formas de acautelamento e preservação deixou claro que a enumeração do dispositivo é meramente exemplificativa". Em outras palavras, o legislador constituinte enumerou alguns dos instrumentos jurídicos hábeis à proteção do patrimônio cultural, mas nada impede que outros meios de proteção já consagrados no próprio texto constitucional, ou instituídos pela legislação ordinária, também possam ser utilizados na tutela do meio ambiente cultural.

Embora o tombamento não seja o único, e nem necessariamente, o mais efi$\mathrm{caz}^{18}$ dos instrumentos para a tutela do patrimônio cultural, desde sua consagração pelo Decreto-lei n. ${ }^{\circ}$ 25/1937, foi confundido com o próprio conceito de preservação, como observa Sônia Rabello. ${ }^{19}$

Comumente, costuma-se entender e usar como se sinônimos fossem os conceitos de preservação e de tombamento. É importante, porém, distingui-los, já que diferem quanto aos seus efeitos no mundo jurídico, mormente para a apreensão mais rigorosa do que seja o ato de tombamento.

da competência legislativa do município para a tutela do meio ambiente natural, cujo entendimento pode ser transposto para o âmbito do meio ambiente cultural, defende que: "em matéria ambiental, desponta a primazia do município na atividade legiferante, assim como no desenvolvimento das atividades administrativas envolvendo o meio ambiente. Infere-se também que o princípio da subsidiariedade reserva à municipalidade somente funções, tarefas e serviços que o município pode cumprir de maneira eficiente, cabendo às entidades estatais superiores a realização das tarefas que o município não consegue desempenhar satisfatoriamente. Constata-se, desse modo, o caráter supletivo inserido no princípio da subsidiariedade, consistente na possibilidade de atuação do ente federativo maior nos casos de omissão ou inépcia do ente federativo inferior. E, mesmo assim, a atuação do ente federativo maior deve ser precedida de cooperação em relação ao ente menor".

18 Neste sentido, pronuncia-se Marcos Paulo de Souza Miranda (2006, p. 101): "Infelizmente está ainda arraigada na consciência de grande parte da população brasileira que somente o tombamento é capaz de proteger eficazmente o nosso patrimônio cultural, o que é uma grande falácia. Além de não se prestar para a tutela de alguns bens culturais, como os imateriais, por exemplo, o tombamento é apenas uma das muitas alternativas existente para a proteção do patrimônio cultural".

19 No mesmo sentido, ver Marchesan (2007, p. 212). 


\begin{abstract}
Preservação é o conceito genérico. Nele podemos compreender toda e qualquer ação do Estado que vise conservar a memória de fatos ou valores culturais de uma Nação. É importante acentuar este aspecto já que, do ponto de vista normativo, existem várias possibilidades de formas legais de preservação. A par da legislação, há também as atividades administrativas do Estado que, sem restringir ou conformar direitos, se caracterizam como ações de fomento que têm como consequência a preservação da memória. Portanto, o conceito de preservação é genérico, não se restringindo a uma única lei, ou forma de preservação específica. (2009, p. 19).
\end{abstract}

O tombamento é um dos diversos instrumentos, com assento constitucional, destinados à proteção e à preservação do meio ambiente cultural. Embora não seja o único, o tombamento é o mais difundido instituto de tutela de bens culturais materiais no Direito brasileiro, tendo sido disciplinado pela primeira vez pelo Decreto-lei n. ${ }^{\circ} 25 / 1937 .{ }^{20} \mathrm{O}$ regime jurídico do tombamento, introduzido pelo Decreto-lei n. ${ }^{\circ}$ 25/1937, só foi modificado pelo Decreto-lei n. ${ }^{\circ} 3.866 / 1941$, que dispõe sobre o cancelamento do tombamento pelo Presidente da República, e pela Lei n. ${ }^{\circ} 6.292 / 1975$, que introduziu a homologação ministerial neste procedimento. O Decreto-lei n. ${ }^{\circ}$ 25/1937 foi recepcionado, em sua essência, pela Constituição Federal de 1988, sendo, ainda hoje, a norma geral que disciplina o tombamento no Brasil.

Inexiste consenso na doutrina acerca da natureza jurídica do tombamento, podendo ser identificadas, pelo menos, três posições distintas: a) o tombamento como modalidade de limitação administrativa; b) o tombamento como modalidade de servidão administrativa; e c) o tombamento como modalidade autônoma de intervenção estatal na propriedade.

A primeira corrente doutrinária entende que o tombamento constitui modalidade de limitação administrativa, sendo apontados como defensores de tal entendimento José Cretella Júnior, Themístocles Bandão Cavalcante (Cf. MIRANDA, 2006, p. 110; LEITE, 2011, p. 27-28; CARVALHO FILHO, 2010, p. 871) e Sônia Rabello (2009, p. 128-145). Segundo tal entendimento, o tombamento é restrição geral e gratuita imposta indeterminadamente pelo Poder Público às propriedades (cf. MIRANDA, 2006, p. 110). O tombamento, como limitação administrativa, funda-se no poder de polícia administrativa, já que busca restringir direitos de particulares em função do interesse da coletividade. Neste sentido, as lições de Sônia Rabello:

O tombamento, conforme previsto no Decreto-lei 25/37, impõe ao proprietário da coisa tombada, seja ela móvel ou imóvel, obrigação de con-

20 Para compreensão do contexto histórico de elaboração do referido diploma normativo, ver Miranda (2006, p. 4-5). 
servação, condicionando, sobretudo, seu uso adequado e a obrigação de zelar por suas características culturais. Impõe aos prédios vizinhos, em função da coisa imóvel tombada, a obrigação de uso adequado de sua propriedade de modo a não prejudicar a ambiência do bem tombado. Traduz-se, por isso, o tombamento numa limitação de uso, acoplado a uma obrigação de fazer - a conservação da coisa. O tombamento não retira do proprietário a exclusividade do domínio; o proprietário continua no desfrute da coisa, mormente na sua possibilidade de uso econômico. Caracterizam-se assim o tombamento e as restrições impostas à vizinhança da coisa tombada como limitações administrativas ao uso e gozo da propriedade em função do interesse público de proteção do patrimônio cultural. (2009, p. 139).

A segunda corrente defende que o tombamento é modalidade de servidão administrativa. Filiaram-se a este entendimento Lúcia Valle Figueiredo (2003, p. 300), Adilson de Abreu Dallari (1988, p. 37-41), Diogenes Gasparini (2008, p. 803-804), Ana Tereza Ribeiro da Silveira (2011, p. 330) e, até a $26^{\text {a }}$ edição de seu Curso de direito administrativo, Celso Antônio Bandeira de Mello (2005, p. 833). ${ }^{21}$ Para os defensores desta interpretação, o tombamento constitui modalidade de servidão administrativa, pois, ao contrário da limitação administrativa, incide sobre bem determinado, causando, ao seu proprietário, ônus maior do que o suportado pelos demais membros da coletividade - sacrifício de direito (Cf. BANDEIRA DE MELLO, 1987, p. 68-71). Assim, como no direito privado, a servidão administrativa caracteriza-se pela constituição de um direito real sobre a coisa alheia - ônus real.

A terceira corrente, que tem ganhado prestígio doutrinário nos últimos tempos, concebe o tombamento como modalidade autônoma de intervenção estatal sobre propriedade. São defensores de tal concepção teórica Maria Sylvia Zanella Di Pietro (2008, p. 137-138), ${ }^{22}$ Celso Antônio Bandeira de Mello (2011, p. 918), José dos Santos Carvalho Filho (2010, p. 871-873), Dirley da Cunha Júnior (2009, p. 390-391) e Marçal Justen Filho (2010, p. 605). Esse entendimento pode ser sintetizado no seguinte trecho das lições de José dos Santos Carvalho Filho:

${ }^{21} \mathrm{O}$ autor reviu seu entendimento, conforme relata nas edições recentes de sua obra: "Até a $26^{\mathrm{a}}$ edição deste Curso exprimimos o entendimento de que o tombamento era modalidade de servidão administrativa. Estávamos errados. Convenceu-nos disso a argumentação da administrativista Adriana Zandonade, em tese de doutorado que estava sob nossa orientação" (BANDEIRA DE MELLO, 2011, p. 918). Para aprofundamento no anterior posicionamento do autor, cf. BANDEIRA DE MELLO, 1987, p. 65-73.

22 A própria autora relata que alterou seu entendimento sobre a natureza jurídica do tombamento. Vejamos as lições da ilustre administrativista: "Preferimos, por isso, considerar o tombamento categoria própria, que não se enquadra nem como simples limitação administrativa, nem como servidão. Nesse ponto, evoluímos um pouco em relação ao entendimento adotado na tese 'Servidão Administrativa' (1978, p. 27)" (DI PIETRO, 2008, p. 138). 
Temos para nós que o tombamento não é nem servidão nem limitação administrativa. Trata-se realmente de instrumento especial de intervenção restritiva do Estado na propriedade privada, com fisionomia própria e inconfundível com as demais formas de intervenção. Além disso, tem natureza concreta e específica, razão por que, diversamente das limitações administrativas, se configura como uma restrição de uso da propriedade. Podemos, pois, concluir que a natureza jurídica do tombamento é a de se qualificar como meio de intervenção do Estado consistente na restrição de uso de propriedades determinadas. (2010, p. 872).

Seguindo a mesma linha, posiciona-se Maria Sylvia Zanella Di Pietro:

O tombamento tem em comum com a limitação administrativa o fato de ser imposto em benefício de interesse público; porém dela difere por individualizar o imóvel.

Comparado com a servidão, o tombamento a ela se assemelha pelo fato de individualizar o bem; porém dela difere porque falta a coisa dominante, essencial para caracterizar qualquer tipo de servidão, seja de direito público ou privado.

Preferimos, por isso, considerar o tombamento categoria própria, que não se enquadra nem como simples limitação administrativa, nem como servidão. (2008, p. 137-138).

O presente estudo não ambiciona alcançar resposta definitiva acerca da natureza jurídica do tombamento, embora, em princípio, pareça coerente concluir que o tombamento possui traços sui generis que o distingue das demais formas de intervenção estatal sobre a propriedade.

\section{COMPETÊNCIA doS MUNICÍPIOS PARA REALIZAR O TOMBAMENTO DE BENS PÚBLICOS ESTADUAIS E FEDERAIS}

Parcela da doutrina nega competência aos municípios para realizar tombamento de bens públicos estaduais e federais. Tal corrente doutrinária sustenta a aplicação analógica do art. $2^{\circ}, \S 2^{\circ}$ do Decreto-lei n. ${ }^{0} 3.365 / 1941,{ }^{23}$ que disciplina as desapropriações, ao instituto do tombamento. Em outras palavras, a União teria competência para tombar bens estaduais, distritais e municipais; já, os estados teriam competência para tombar bens municipais. No entanto, segundo tal entendimento, os estados e os municípios não teriam competência para tombar bens federais, assim como os

${ }_{23}$ Dispõe o $\S 2^{\circ}$ do art. $2^{\circ}$ do Decreto-lei n ${ }^{\circ} 3.365 / 1941$ : “Os bens do domínio dos Estados, Municípios, Distrito Federal e Territórios poderão ser desapropriados pela União, e os dos Municípios pelos Estados, mas, em qualquer caso, ao ato deverá preceder autorização legislativa”. 
municípios careceriam de competência para tombar bens estaduais. Vejamos, neste sentido, as lições de José dos Santos Carvalho Filho:

Quanto aos bens públicos, entendemos que, por interpretação analógica ao art. $2^{\circ}, \S 2^{\circ}$, do Decr.-lei $n^{\circ} 3.365 / 41$, que regula as desapropriações, a União pode tombar bens estaduais, distritais e municipais, e os Estados podem fazê-lo em relação aos bens do Município. Entretanto, em observância também à natureza dos interesses tutelados pelos entes federativos das diversas esferas, parece-nos não possam as entidades menores instituir, manu militari, tombamento sobre bens pertencentes aos maiores, isto é, o Município não pode fazê-lo sobre bens estaduais e federais, nem os Estados sobre bens da União. Nestes casos, a entidade menor interessada deve obter autorização do ente público maior a quem pertencer o bem a ser tombado; só assim nos parece compatível a interpretação do art. 23 , III, da CF, que confere a todas as pessoas federativas competência comum para proteger bens de valor histórico, artístico e cultural. (2010, p. 876).

O referido entendimento doutrinário tem ganhado certo prestígio jurisprudencial. Em 2009, a Advocacia-Geral do Estado de Minas Gerais obteve, por meio de mandado de segurança (MS n. ${ }^{\circ}$ 0145.05.271152-3), a invalidação de tombamento de imóvel estadual realizado pelo município de Juiz de Fora/MG. Na decisão de primeiro grau, o magistrado, ao conceder a segurança requerida pelo Estado de Minas Gerais, entendeu que "não há admissibilidade de tombamento de bem estadual pelo município, em consideração ao princípio da hierarquia federativa, havendo, destarte, direito líquido e certo a amparar o impetrante". ${ }^{24}$

A tese daqueles que afirmam a incompetência do município para realizar o tombamento de bens públicos estaduais e federais, baseia-se, em síntese, em dois argumentos: a) existência de hierarquia entre os entes federados; e b) equiparação, ou semelhança entre os institutos do tombamento e o da desapropriação de forma a possibilitar a utilização de analogia, fundada em norma infraconstitucional, para restringir o alcance da competência dos municípios na proteção e preservação do patrimônio cultural local.

$\mathrm{O}$ argumento de existência de hierarquia entre os entes federados, além de contrário à própria teoria geral do federalismo, ${ }^{25}$ é insustentável na sistemática constitucional brasileira. A Constituição Federal consagra a autonomia político-administrativa da União, dos estados, do Distrito Federal e dos municípios (art. 18) e reparte a

${ }^{24}$ Cf. MINAS GERAIS. Advocacia Geral do Estado. Município não pode tombar bem do Estado. Disponível em: <http://www.pge.mg.gov.br/comunicacao/790-municipio-nao-pode-tombar-bem-do-estado>. Acesso em: 15 out. 2011.

25 Sobre o estudo da teoria geral do federalismo, consultar Baracho (1982). 
competência legislativa e administrativa entre os entes (arts. 21, 22, 23, 24, 25 e 30). Ao delimitar a competência dos entes políticos, o constituinte reafirma sua autonomia político-administrativa e a inexistência de hierarquia entre eles.

Em especial, no que tange ao meio ambiente cultural, conforme analisamos anteriormente neste estudo, a Constituição Federal estabeleceu competência comum da União, dos estados, do Distrito Federal e dos municípios (art. 23, III, IV e V) para realizar sua proteção, ${ }^{26}$ sendo que, ao município, foi reservada a tutela do patrimônio cultural em seu aspecto local (art. 30, IX). Leciona Sônia Rabello (2009, p. 34): "a União terá competência para proteger bens que tiverem importância nacional; os Estados, bens que tiverem significado regional; e os Municípios, aqueles bens de interesse local". Partindo da premissa acima, a citada autora conclui que:

É evidente que, tendo um bem importância nacional, sua importância regional, ou local, é quase, automaticamente, decorrente. Esta lógica não implica, entretanto, o exercício necessariamente vinculado da competência de proteção daqueles outros entes políticos. Eles a exercerão, na forma estabelecida em legislação pertinente que, de modo geral, atribui ao Poder Executivo a competência para fixar, por ato administrativo, os bens a serem protegidos. Para um determinado bem que tenha importância nacional, fica bastante fácil demonstrar sua importância regional ou local; mas o inverso pode não ser verdadeiro. Há bens que têm importância exclusivamente regional ou local; nesta última hipótese, apenas o Estado, ou Município, terá interesse jurídico em protegê-los; um bem de importância apenas regional será protegido pelo Estado-membro, refugindo à União o interesse da proteção. (2009, p. 34).

Se chegássemos à conclusão de que realmente o município carece de competência para proceder ao tombamento de bens públicos estaduais e federais, a competência municipal para a proteção do patrimônio cultural local estaria fragilizada, na medida em que os bens culturais de relevância exclusivamente local estariam despidos de proteção, quando integrantes do patrimônio da União, dos Estados e de suas pessoas jurídicas de direito público. ${ }^{27}$

26 Não há que se falar em conflito de competência entre os entes políticos, pois o constituinte determinou que eles devem cooperar, nos termos da legislação complementar a que alude o art. 23, parágrafo único da Constituição Federal, "tendo em vista o equilíbrio do desenvolvimento e do bem-estar em âmbito nacional".

27 Nesta linha, posiciona-se Carlos Frederico Marés de Souza Filho (2008, p. 124): "Imaginemos a hipótese de um bem estadual ou federal, que seja de suma importância para o Município, mas sem importância para as outras esferas. Neste caso, só o Município poderá promover a proteção, porque só a ele interessa, não importando quem seja o proprietário". 
Outro ponto que não se sustenta é afirmação de que haveria equiparação, ou semelhança, entre os institutos do tombamento e o da desapropriação, de forma a possibilitar a utilização de analogia para restringir o alcance da competência dos municípios para a proteção do patrimônio cultural local. Conforme destaca Maria Helena Diniz, para recorrer à analogia, faz-se necessário, além da inexistência de norma específica disciplinando a situação concreta, que:

\begin{abstract}
o elemento de identidade entre os casos não seja qualquer um, mas sim fundamental ou de fato que levou o legislador a elaborar o dispositivo que estabelece a situação à qual se quer comparar a norma não contemplada. Terá de haver uma verdadeira e real semelhança e a mesma razão entre ambas as situações. Meras semelhanças aparentes, afinidades formais ou identidades relativas a pontos secundários não justificam o emprego da argumentação analógica. (2001, p. 13).
\end{abstract}

Não há semelhança entre os institutos da desapropriação e do tombamento capaz de autorizar a aplicação analógica do art. $2^{\circ}, \S 2^{\circ}$ do Decreto-Lei n. ${ }^{\circ} 3.365 / 1941$ ao instituto jurídico do tombamento. A doutrina é pacífica em distinguir os dois institutos, sob o argumento de que o tombamento implica mera restrição parcial ao direito de propriedade; já, a desapropriação é a forma mais drástica de intervenção estatal na propriedade. Vejamos, neste sentido, as lições de Maria Sylvia Zanella Di Pietro:

O tombamento é sempre uma restrição parcial, não impedindo ao particular o exercício dos direitos inerentes ao domínio; por isso mesmo, não dá, em regra, direito a indenização; para fazer jus a uma compensação pecuniária, o proprietário deverá demonstrar que realmente sofreu algum prejuízo em decorrência do tombamento.

Se, para proteger o bem, o Poder Público tiver que impor restrição total, de modo que impeça o proprietário do exercício de todos os poderes inerentes ao domínio, deverá desapropriar o bem e não efetuar o tombamento, uma vez que as restrições possíveis, nesta última medida, são apenas as que constam da lei, nela não havendo a previsão de qualquer imposição que restrinja integralmente o direito de propriedade. (2008, p. 129).

José dos Santos Carvalho Filho, ao defender a semelhança entre os institutos da desapropriação ao do tombamento, capaz de justificar a aplicação analógica do art. $2^{\circ}, \S 2^{\circ}$ do Decreto-Lei n. 3.365/1941 ao instituto ao tombamento, incorre em incoerência, pois afirma, em passagem citada anteriormente neste estudo, que o tombamento constitui "instrumento especial de intervenção restritiva do Estado na propriedade privada, com fisionomia própria e inconfundível com as demais formas de intervenção" (CARVALHO FILHO, 2010, p. 872). 
É importante destacar que outra parcela da doutrina defende a possibilidade de tombamento municipal de bens públicos estaduais e federais. Neste sentido, vale transcrever a posição incisiva de Carlos Frederico Marés de Souza Filho: ${ }^{28}$

\begin{abstract}
Por que razão estariam fora dessa proteção os bens estaduais e federais, se o tombamento não altera a propriedade do bem? A natureza jurídica do domínio não é tocada pelo tombamento, que apenas impõe limitações e restrições e agrega um direito coletivo difuso ou socioambiental sobre o bem. Os bens federais e estaduais estão sujeitos a todas as limitações urbanísticas e, com igual ou maior razão, ao tombamento.

Para que houvesse isenção, ela deveria constar da Constituição, mas não consta. O Município tem um poder/dever de promover a proteção, inscrito na Constituição e não, o contrário. Assim, o ente municipal que disponha de lei de tombamento poderá tombar bens estaduais e federais, tanto quanto impor quaisquer outras limitações administrativas ou instrumentos de proteção cultural. (2008, p. 124-125).
\end{abstract}

Por fim, deve-se salientar que o Superior Tribunal de Justiça já se posicionou contrário à tese daqueles que sustentam a aplicação analógica do art. $2^{\circ}, \S 2^{\circ}$ do Decreto-Lei n. ${ }^{\circ} 3.3365 / 1941$ para o instituto ao tombamento:

\title{
ADMINISTRATIVO - TOMBAMENTO - COMPETÊNCIA MUNI- CIPAL.
}

1. A Constituição Federal de 88 outorga a todas as pessoas jurídicas de Direito Público a competência para o tombamento de bens de valor histórico e artístico nacional.

2. Tombar significa preservar, acautelar, preservar, sem que importe o ato em transferência da propriedade, como ocorre na desapropriação.

3. O Município, por competência constitucional comum - art. 23, III -, deve proteger os documentos, as obras e outros bens de valor histórico, artístico e cultural, os monumentos, as paisagens naturais notáveis e os sítios arqueológicos.

4. Como o tombamento não implica em transferência da propriedade, inexiste a limitação constante no $\operatorname{art.} 1^{\circ}, \S 2^{\circ}$, do DL 3.365/1941, que pró́be o Município de desapropriar bem do Estado.

28 No mesmo sentido, Jair Eduardo de Santana (1998, p. 153), ao defender a competência do município para legislar sobre proteção e preservação do patrimônio cultural, afirma a competência do ente local para proceder tombamento de bens estaduais e federais: "Assim, tanto pelo disposto no artigo 24 , inciso VII, e $\S 1^{\circ}$, como por aquilo que se lê nos artigos 23, inciso III, e 30, inciso IX, em combinação com o estatuído no art. 30, incisos I e II (todos da Constituição Federal), não temos dúvida que o Município pode dispor legislativamente sobre o tema tombamento. E não só isso. Dizemos que o Município pode tombar, além dos seus, bens da União e dos Estados, não havendo proibição semelhante àquela relativa às desapropriações". 
5. Recurso improvido. (BRASIL. Superior Tribunal de Justiça. Recurso Ordinário em Mandado de Segurança ${ }^{\circ}$ 18.952-RJ. Relatora: Ministra Eliane Calmon. D.J. 30/05/2005.).

Seguindo a lógica do federalismo brasileiro, para que o município possa exercer de forma plena a competência para a proteção do meio ambiente cultural, ele deve ser capaz de manejar todos os instrumentos jurídicos hábeis à tutela do patrimônio cultural, inclusive, se necessário, proceder ao tombamento de bens públicos municipais, estaduais ou federais. O entendimento de que o município não dispõe de competência para realizar o tombamento de bens estaduais e federais, além de violar a distribuição constitucional de competências, fragiliza a proteção dos bens culturais de relevância exclusivamente local, contrariando o próprio conceito amplo e pluralista de patrimônio cultural constitucionalmente consagrado.

\section{Conclusão}

Como síntese do exposto no presente estudo, apresentamos as seguintes conclusões:

1. a doutrina contemporânea entende que o patrimônio cultural está compreendido na noção de meio ambiente, embora estes temas tenham sido tratados em capítulos distintos da Constituição Federal de 1988, por questão de sistematização legislativa;

2. seguindo a tendência de conferir tratamento homogêneo entre o meio ambiente natural e o meio ambiente cultural, o texto constitucional estabeleceu competência comum da União, dos estados, do Distrito Federal e dos municípios para a realização de medidas administrativas voltadas para a proteção e preservação do patrimônio cultural, sendo reservada aos dois últimos a competência para a tutela do interesse local;

3. embora não haja consenso na doutrina e na jurisprudência, conclui-se, com base em análise sistêmica do texto constitucional, defendida por parcela da doutrina, que o município possui competência para legislar sobre proteção ao patrimônio cultural local, suplementando, no que couber, a legislação federal e estadual;

4. o tombamento é um dos instrumentos, com assento constitucional, destinados à proteção e à preservação do meio ambiente cultural. Apesar da polêmica doutrinária em torno da natureza jurídica do tombamento, pode-se concluir que ele caracteriza-se como modalidade autônoma de intervenção estatal sobre propriedade;

5. o município possui competência para proceder ao tombamento de bens públicos municipais, estaduais e federais. Carece de sustentação o argumento 
daqueles que tentam mitigar a competência dos municípios para a tutela do patrimônio cultural local, por meio da aplicação analógica do art. $2^{\circ}, \S 2^{\circ}$ do Decreto-lei n. ${ }^{\circ} 3.365 / 1941$, que disciplina as desapropriações, ao instituto do tombamento.

\section{REFERÊNCIAS}

BANDEIRA DE MELLO, C. A. Curso de direito administrativo. 18. ed. São Paulo: Malheiros, 2005.

BANDEIRA DE MELLO, C. A. Curso de direito administrativo. 28. ed. São Paulo: Malheiros, 2011.

BANDEIRA DE MELLO, C. A. Tombamento e dever de indenizar. Revista de Direito Público. São Paulo, v. 20, n. 81, p. 65-73, jan.-mar. 1987.

BARACHO, J. O. Teoria geral do federalismo. Belo Horizonte: Fumarc-UCMG, 1982.

BRASIL. Superior Tribunal de Justiça. Administrativo. Tombamento. Competência Municipal. Recurso Ordinário em Mandado de Segurança $n^{\circ}$ 18.952-RJ. Relatora: Ministra Eliane Calmon. D.J. 30/05/2005. Disponível em: <http \www.stj.jus.br>. Acesso em: 13 out. 2011.

BRASIL. Supremo Tribunal Federal. Limitação administrativa. Prédio urbano: cultural e ambiental do bairro do Cosme Velho. Decreto Municipal 7.046/87. Competência e Legalidade. Recurso Extraordinário no 121.140-7-RJ. Relator: Ministro Maurício Corrêa. D. J. 23/08/2002. Disponível em: $<$ http $\backslash$ www.stf.jus.br $>$. Acesso em: 15 out. 2011.

BRATZ, J. A. Competência do município para legislar em matéria ambiental à luz do princípio da subsidiariedade. Interesse Público, Belo Horizonte, v. 13, n. 67, p. 251-274, 2011.

BRAZ, P. Direito municipal na constituição. São Paulo: Livraria de Direito, 1994. CARVALHO FILHO, J. S. Manual de direito administrativo. 23. ed. Rio de Janeiro: Lumen Juris, 2010.

CASTRO, J. N. Direito municipal positivo. 6. ed. Belo Horizonte: Del Rey, 2006.

COPOLA, G. O meio ambiente cultural e sua proteção. Boletim de Direito Administrativo. São Paulo, v. 20, n. 6, p. 641-650, jun. 2004. 
CUNHA JÚNIOR, D. Curso de direito administrativo. 7. ed. Salvador: Jus Podivm, 2009.

CUSTÓDIO, H. B. Meio ambiente urbano. Boletim de Direito Administrativo, São Paulo, v. 11, n. 1, p. 34-41, jan. 1995.

DALLARI, A. A. Tombamento. Revista de Direito Público, São Paulo, v. 21, n. 86, p. 37-41. abr.-jun. 1988.

DI PIETRO, M. S. Z. Direito administrativo. 21 ed. São Paulo: Atlas, 2008.

DINIZ, M. H. Lei de ntrodução ao Código Civil Brasileiro Interpretada. 7. ed. São Paulo: Saraiva, 2001.

FARIA, E. F. O tombamento e seus reflexos. In: DIAS, M. T. F.; PAIVA, C. M. S. (Coords.). Direito e proteção do patrimônio cultural imóvel. Belo Horizonte: Fórum, 2010. p. 53-91.

FERRARI, R. M. M. N. Elementos de direito municipal. São Paulo: Revista dos Tribunais, 1993.

FIGUEIREDO, L. V. Curso de direito administrativo. 6. ed. São Paulo: Malheiros, 2003.

FIORILLO, C. A. P. Curso de direito ambiental. 12. ed. São Paulo: Saraiva, 2011.

GASPARINI, D. Direito administrativo. 13. ed. São Paulo: Saraiva, 2008.

JUSTEN FILHO, M. Curso de direito administrativo. Belo Horizonte: Fórum, 2010.

LEITE, L. G. A competência do município em meio ambiente. Boletim de Direto Administrativo, São Paulo, v. 9, n. 11, p. 651-654, nov. 1993.

LEITE, R. Tombamento: decreto-lei $n^{\circ}$ 25, de 30 de novembro de 1937. Salvador: JusPodivm, 2011.

MARCHESAN, A. M. M. A tutela do patrimônio cultural sob o enforque do direito ambiental. Porto Alegre: Livraria do Advogado, 2007.

MEIRELLES, H. L. Direito municipal brasileiro. 15. ed. São Paulo: Malheiros, 2006.

MINAS GERAIS. Advocacia Geral do Estado. Município não pode tombar bem do Estado. Disponível em: <http://www.pge.mg.gov.br/comunicacao/790-municipio-nao-pode-tombar-bem-do-estado>. Acesso em: 15 out. 2011.

MINAS GERAIS. Tribunal de Justiça. Tombamento. Município. Os municípios não têm competência concorrente para legislar sobre a proteção de seu patrimônio histó- 
rico-cultural, mas devem utilizar os instrumentos de proteção previstos na legislação federal e estadual. Apelação Cível no 000.199.546-3/00. Relator: Desembargador Aloysio Nogueira, julgado em 31/06/2001. Disponível em: $<$ http $\mid$ www.tjmg.jus. br>. Acesso em: 12 out. 2011.

MINAS GERAIS. Tombamento - ato originário de legislação municipal - competência - direito líquido e certo - inocorrência - legalidade. Tem o Município competência para legislar sobre a matéria - Inteligência dos arts. 23 e 24 da Constituição Federal. Improvado o alegado direito líquido e certo, é de ser denegada a ação mandamental. Apelação Civil no 000.221.584-6/00. Relator: Desembargador Francisco Figueiredo, julgado em 05/06/2002. Disponível em: $<$ http $\backslash w w w . t j m g . j u s . b r>$. Acesso em: 12 out. 2011.

MINAS GERAIS. Tombamento de imóvel - competência legislativa do município - inteligência dos arts. 24, VII; 30, II e 216, § $1^{\circ}$, da Constituição Federal - Lei $n^{\circ}$ 7.282/88 de Juiz de Fora. Constitucionalidade. Apelação Civil no 000.256.230-4/00. Relator: Desembargador Bady Curi, julgado em 07/11/2002. Disponível em: $<$ http \\ www.tjmg.jus.br>. Acesso em: 12 out. 2011.

MIRANDA, M. P. S. Tutela do patrimônio cultural brasileiro. Belo Horizonte: Del Rey, 2006.

NABAIS, J. C. Considerações sobre o quadro jurídico do patrimônio cultural em Portugal. In: DIAS, M T. F.; PAIVA, C. M. S. (Coords.). Direito e proteção do patrimônio cultural imóvel. Belo Horizonte: Fórum, 2010. p. 93-112.

PAIVA, C. M. S. O regime jurídico do bem cultural edificado no Brasil. Ouro Preto: UFOP, 2010.

PIRES, M. C. S. Autonomia municipal no estado brasileiro. Revista de Informação Legislativa, Brasília, v. 36, n. 142, p. 143-166, abr.-jun. 1999.

PIRES, M. C. S. Direito urbanístico, meio ambiente e patrimônio cultural. In: DIAS, M. T. F.; PAIVA, C. M. S. (Coords.). Direito e proteção do patrimônio cultural imóvel. Belo Horizonte: Fórum, 2010. p. 137-181.

RABELLO, S. O Estado na preservação dos bens culturais: o tombamento. Edição Especial. Rio de Janeiro: IPHAN, 2009.

REISEWITZ, L. Direito ambiental e patrimônio cultural: direito à preservação da memória, ação e identidade do povo brasileiro. São Paulo: Juarez de Oliveira, 2004. SANTANA, J. E. Competências legislativas municipais. 2. ed. Belo Horizonte: Del Rey, 1998. 
SILVA, E. P. Cultura e desenvolvimento humano: o papel do estado e da sociedade civil na consolidação da cidadania cultural. Revista de Informação Legislativa, Brasília, v. 47, n. 185, p. 105-122, jan.-mar. 2010.

SILVA, J. A. Curso de direito constitucional positivo. 24. ed. São Paulo: Malheiros, 2005.

SILVA, J. A. Direito ambiental constitucional. 2. ed. São Paulo: Malheiros, 1998.

SILVA, J. A. Ordenação constitucional da cultura. São Paulo: Malheiros, 2001.

SILVEIRA, A. T. R. Elementos fundamentais do tombamento. In: DALLARI, A. A.; DI SARNO, D. C. L. (Coords.). Direito urbanístico e ambiental. 2. ed. Belo Horizonte: Fórum, 2011. p. 285-312.

SOUZA FILHO, C. F. M. Bens culturais e sua proteção jurídica. 3. ed. Curitiba: Juruá, 2008.

TOMASEVICIUS FILHO, E. O tombamento no direito administrativo e internacional. Revista de Informação Legislativa. Brasília, v. 41, n. 163, p. 231-247, jul.-set. 2004.

TRENNEPOHL, T. Direito ambiental. 3. ed. Salvador: Jus Podivm, 2008.

Submetido em: 10/7/2012

Aceito em: 13/8/2012 